\title{
Resolving the chronology of recent lake sediments: an example from Devils Lake, North Dakota
}

\author{
Heather A. Jacobson' \& Daniel R. Engstrom \\ Limnological Research Center, University of Minnesota, Minneapolis, MN 55455 ; ${ }^{1}$ Present Address: \\ Department of Botany and Plant Pathology, University of Maine, Orono, ME 04469, USA
}

Received 17 June 1988; accepted 13 March 1989

Key words: chronostratigraphy, pollen analysis, ${ }^{210} \mathrm{~Pb}$ dating, North Dakota, Salsola iberica

\begin{abstract}
Devils Lake is a closed, saline lake in North Dakota; it is typical of lake basins in the Great Plains Region, where windy conditions and fluctuating water-levels disturb sediment and confound chronostratigraphy. Pollen analysis and ${ }^{210} \mathrm{~Pb}$ dating of two cores collected from bathymetrically contrasting embayments demonstrate (1) how certain agriculture-related pollen types differ in their value as chronostratigraphic markers, (2) how pollen and ${ }^{210} \mathrm{~Pb}$ stratigraphies can be reconciled to determine the approximate depth of sediment mixing, and (3) the importance of coring-site selection, especially in lakes with unstable sedimentary conditions.
\end{abstract}

\section{Introduction}

A reliable chronology is essential when lake sediments are used to study environmental history of a region or locality. As the time period of interest becomes shorter, dating accuracy and precision must increase. The most common radiometric method used for dating lake sediments younger than 150 years old is ${ }^{210} \mathrm{~Pb}$. This technique usually assumes a constant supply of ${ }^{210} \mathrm{~Pb}$ to the sediments as well as lack of mixing of sediments after deposition; both are reasonable assumptions in many lakes.

However, many lake basins located in the prairie region of the midwestern United States, including North and South Dakota and parts of Minnesota, present problems. Typically these lakes are shallow (less than $10 \mathrm{~m}$ deep), and winddriven currents can resuspend and move sediment particles. Most lakes in this region are in topographically closed basins and thus are sensitive to climatic change. Fluctuating lake levels can also have significant effects on the rate of supply of both sediment and ${ }^{210} \mathrm{~Pb}$ to a coring site.

Careful site selection can help minimize these problems (Jacobson \& Bradshaw, 1981). Unfortunately, many sites in the Dakota region have dried on one or more occasions during the past 10000 years (some as recently as the 1930's), leaving hiatuses in the stratigraphic record. Chronostratigraphies based on ${ }^{210} \mathrm{~Pb}$ dating of lake sediments of this region must therefore be evaluated carefully and checked by independent means. Pollen analysis, for example, reveals the well-documented history of Euro-American settlement and the introduction of both cultivars and the non-native weed Salsola iberica Senn. \& Pau. (Russian Thistle), the chronostratigraphic significance of which has not been described previously in the literature.

Here we present an example from Devils Lake, North Dakota, demonstrating how a chronology 
based on ${ }^{210} \mathrm{~Pb}$ can be checked with pollen analysis, historical accounts, and lake-level records. The importance of sampling technique, pollen production and transport, and accuracy of historical records in chronostratigraphy is demonstrated. Results derived from two bays with distinctive bathymetry illustrate the importance of coring-site location. ${ }^{210} \mathrm{~Pb}$ and pollen chronologies from an open, wind-stressed bay disagree, while those from a narrow, more protected site correspond well.

\section{Study site}

Devils Lake lies on the Drift Prairie (Simpson, 1929) of northeastern North Dakota $\left(48^{\circ} 05^{\prime} \mathrm{N}\right.$, $\left.98^{\circ} 56^{\prime} \mathrm{W}\right)$. The major portion of the lake is the circular Main Bay $\left(50 \mathrm{~km}^{2}\right)$; Creel Bay $\left(5 \mathrm{~km}^{2}\right)$ is a narrow appendage on the northeast corner of Main Bay (Fig. 1).

Surficial deposits in the area consist of glacial drift containing fragments of Pierre Shale. Lateglacial lacustrine deposits are also present. The

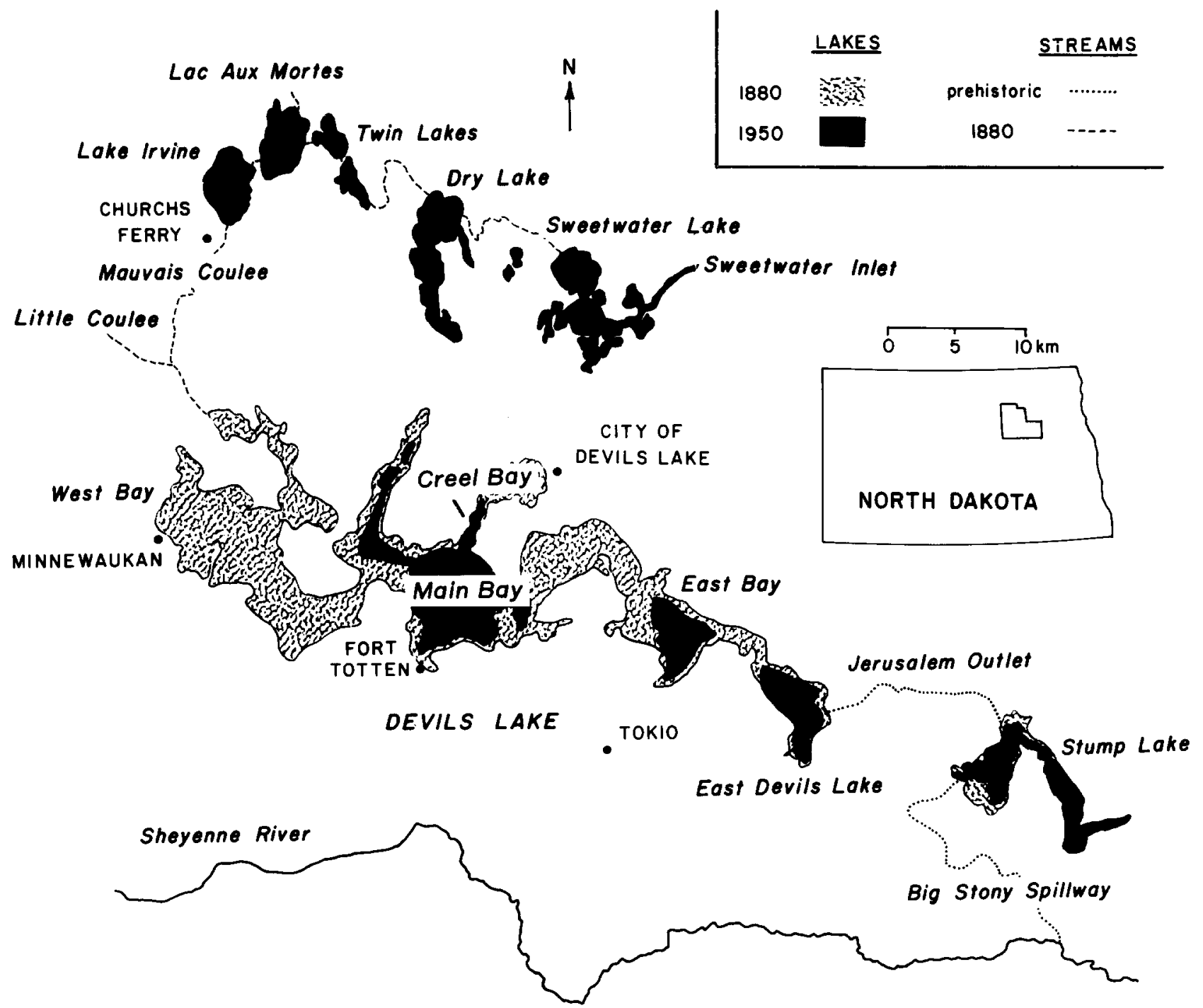

Fig. 1. Map of Devils Lake showing some recent and historical changes in basin morphometry and hydrology (after Aronow, 1957). 
lake is bounded on the south by the North Viking morainal complex, which is characterized by 'knob and kettle' topography. The poorly developed Sweetwater moraine is $10 \mathrm{~km}$ to the northeast. Gently rolling topography of washboard moraine occurs northwest of Devils Lake (Callendar, 1968).

During the Late Wisconsin glaciation, meltwater flowed from Devils Lake through the Jersusalem Outlet to Stump Lake and then through the Big Stoney Spillway to the Sheyenne River (Aronow, 1957) (Fig. 1). Through-drainage terminated after iceretreat, and lakes formed in the individual basins. Until AD 1889, Devils Lake was supplied by water from Mauvaise Coulee, which drained the Sweetwater group of lakes as well as the waters of the Sweetwater Inlet and Little Coulee to the north. Since 1889 Mauvais Coulee has had a dry bed, except during spring thaws (Simpson, 1912; Aronow, 1957). As a result, by 1965 the surface area of the lake had decreased from about 20000 to 4800 ha (Stoermer et al., 1971).

Annual records of water level in Devils Lake (Fig. 2) show a steady decline between 1867 and 1940 and a subsequent rise to the present (Swenson \& Colby, 1955). The maximum depth of the water in 1968 was about $3.5 \mathrm{~m}$ (Callendar, 1968), but today it is near $8.5 \mathrm{~m}$. Stoermer et al. (1971) reported that the water column in Main
Bay could be disturbed by the slightest wind, because of the shallow water depth and pan-like morphometry (Fig. 3).

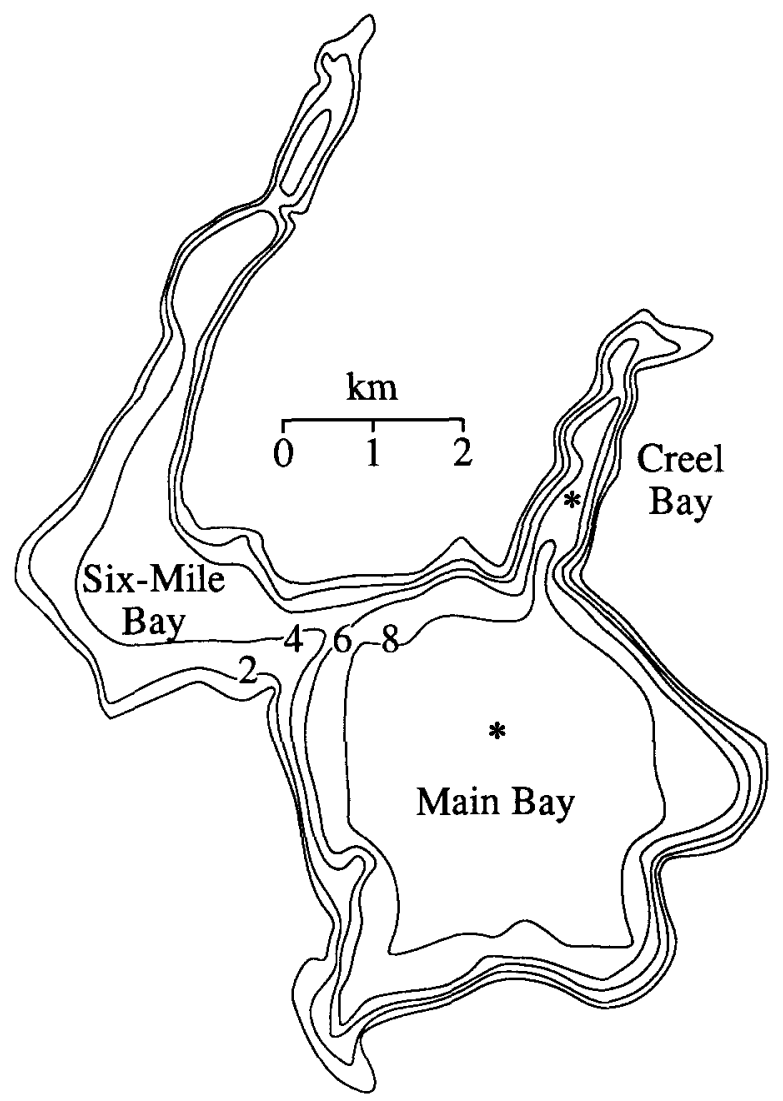

Fig. 3. Bathymetric map of Devils Lake with depth contours in meters. Asterisks denote coring sites.

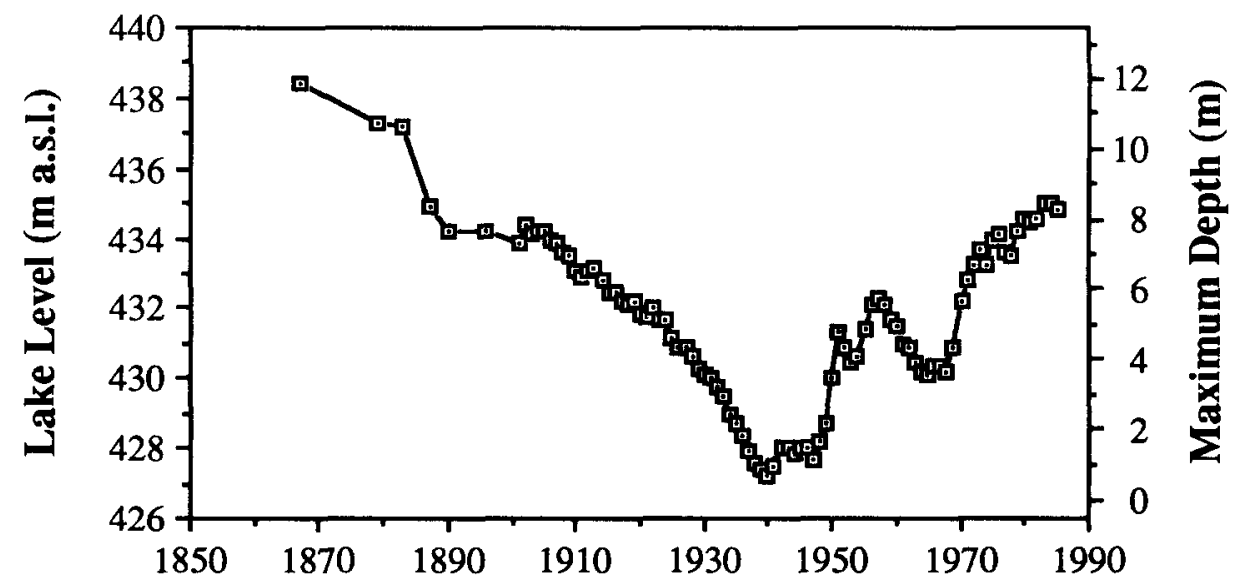

Year

Fig. 2. Historical water level fluctuations in Devils Lake (compiled by the Army Corp of Engineers). 


\section{Settlement history}

In 1859 the first farm was established in the Red River Valley. At that time a settlement of about 100 families of Chippewa Indians was located at Devils Lake. The Turtle Mountain region $100 \mathrm{~km}$ northwest of Devils Lake was settled by European farmers around 1870, when less than 100 acres were under cultivation in North Dakota (Lounsberry, 1919).

North Dakota was surveyed and divided into districts in 1872 and 1873, after which homesteading began, primarily on land along waterways. Homesteaders were alloted quarter-sec- tions ( 160 acres), which were often shared by family members. Initially, only native prairie grasses were harvested in quantity for animal fodder. Within a few years settlers usually had acquired breaking plows and oxen, and were thus able to raise grains (H. R. Rutten, personal communication). For the first decade, however, homesteaders grew only enough crops to feed their families and trade with neighbors. Cash crops such as wheat (Triticum) were not grown until their rapid transport was made possible by construction of railroads (Drache, 1970), which were then the key to agricultural and economic expansion (Fig. 4).

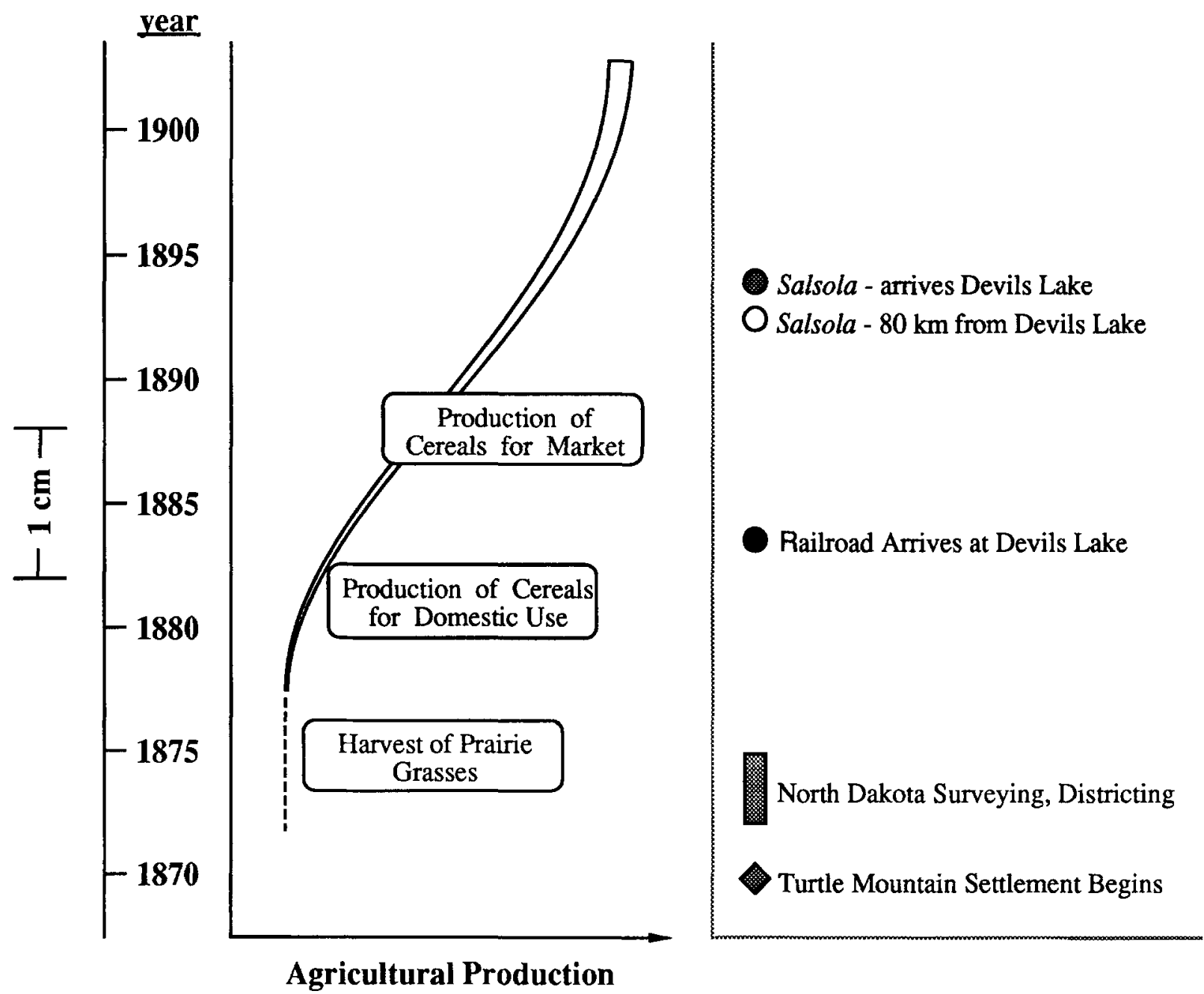

Fig. 4. Schematic representation of agricultural production and historical events in the Devils Lake area relative to their vertical expression in the core. 
The Great Northern Railroad reached the town of Devils Lake in July of 1883. Already Devils Lake was a 'rapidly growing town' large enough to support establishment of other nearby towns (Severson, 1924). Wheat production escalated in the following years, until it became the primary crop in the region (Reitz, 1954).

The region suffered disastrous droughts in 1934 and 1936, and precipitation remained relatively low through 1939. Many farms were abandoned during those 'dust bowl' years (Robsinson, 1966).

\section{Methods}

\section{Sampling}

In July of 1983 a core of the uppermost sediment from the center of Main Bay of Devils Lake (Fig. 3) was obtained with a piston sampler in water $8.4 \mathrm{~m}$ deep. The core was $10 \mathrm{~cm}$ in diameter, about $1 \mathrm{~m}$ long, and watery on top but progressively firmer toward the bottom. While the tube was held vertically in the field, the upper $50 \mathrm{~cm}$ of the core was extruded and sampled at $1-\mathrm{cm}$ intervals, and the lower $50 \mathrm{~cm}$ was cut into $2-\mathrm{cm}$ segments. Each section was sealed in a marked Whirlpak. The samples were homogenized by hand and stored at $4{ }^{\circ} \mathrm{C}$ for 17 months. A core $1 \mathrm{~m}$ long from a depth of $7.5 \mathrm{~m}$ in Creel Bay was collected and subsampled in the same manner in January of 1986.

\section{${ }^{210} \mathrm{~Pb}$ dating}

The two cores from Devils Lake were analyzed for excess ${ }^{210} \mathrm{~Pb}$ activity to determine age and sediment-accumulation rates for the past 200 years. ${ }^{210} \mathrm{~Pb}$ was measured at 32 depth intervals in each core through its grand-daughter product ${ }^{210} \mathrm{Po}$, with ${ }^{208} \mathrm{Po}$ added as an internal yield tracer. The polonium isotopes were distilled from 1-3 g dry sediment at $550{ }^{\circ} \mathrm{C}$ following pretreatment with concentrated $\mathrm{HCl}$ and plated directly (without $\mathrm{HNO}_{3}$ oxidation) onto silver planchettes from a $0.5 \mathrm{~N} \mathrm{HCl}$ solution (modified from Eakins and Morrison, 1978). Activity was measured for $1-4 \times 10^{5} \mathrm{~s}$ with Si-depleted surface detectors and an Ortec Adcam ${ }^{\mathrm{TM}}$ alpha spectroscopy system. Unsupported ${ }^{210} \mathrm{~Pb}$ was calculated by subtracting supported activity from the total activity measured at each level; supported ${ }^{210} \mathrm{~Pb}$ was estimated from the asymptotic activity at depth (the mean of the lowest 7 samples in Creel Bay, and 9 samples in Main Bay). Dates and sedimentation rates were determined according to the c.r.s. (constant rate of supply) model (Appleby \& Oldfield, 1978), with confidence intervals calculated by first-order error analysis of counting uncertainty (Binford, 1988).

\section{Pollen analysis}

Subsamples of $1 \mathrm{~cm}^{3}$ were processed for pollen analysis by standard chemical methods (Faegri \& Iversen, 1975). A known volume of a microsphere suspension of known concentration was added to each subsample in order to determine pollen concentrations (Benninghoff, 1962).

Pollen counts were made with a Leitz Ortholux light microscope at $450 \times$ and $900 \times$ magnifications. At least 300 pollen grains were counted at each level. Identifications were aided by the reference collection of E. J. Cushing, reference texts (Faegri \& Iversen, 1975; McAndrews et al., 1973), and consultation with E. J. Cushing \& E. C. Grimm. Poaceae pollen was separated into the Wild-Grass Group, Hordeum Group, Avenal Triticum Group, and Secale according to the characteristics described by Andersen (1979) \& Beug (1961).

The important indicator genus Salsola was carefully distinguished from similar Chenopodiaceae taxa such as Corispermum. Salsola pollen is subpolyhedric and periporate. It usually has approximately 36 pores, which occur in deep depressions. The depressions are separated by broad ridges with striking scabrate elements (Faegri \& Iversen, 1975). Two species of Salsola occur in the Great Plains, S. iberica, which was introduced in the 19th century, and S. collina Pall., which arrived as early as 1922 but went unrecognized until 1958 (Beadle, 1973; Brooks, 1986). 
Diagrams of pollen percentages show all upland taxa in the pollen sum, including those of clearly local origin. Aquatic and wetland taxa are excluded from the sum, as are 'unknown' and 'indeterminable' grains (Cushing, 1967). Botanical nomenclature follows Great Plains Flora Association (1986).

\section{Results and discussion}

\section{Lead-210}

Lead-210 profiles are generally similar for the Creel and Main Bay cores (Fig. 5). Maximum unsupported activities in the uppermost sediments $(<6.5 \mathrm{pCi} / \mathrm{g})$ are considerably lower than values commonly reported for lakes in forested regions (e.g. Davis et al., 1984), reflecting in part dilution of ${ }^{210} \mathrm{~Pb}$ by a high sediment flux. As a result, supported ${ }^{210} \mathrm{~Pb}$ (derived from in situ decay of ${ }^{226} \mathrm{Ra}$ ) represents a substantial portion of the total activity at all stratigraphic levels. Although such conditions can introduce substantial errors in older dates (Appleby \& Oldfield, 1988), estimates of supported ${ }^{210} \mathrm{~Pb}$ (from the asymptote of total activity) are highly precise and nearly identical for the two cores $(0.78 \pm 0.02$ and $0.80 \pm 0.03$ ), lending confidence to our calculated values for unsupported ${ }^{210} \mathrm{~Pb}$.

In both cores unsupported activity decreases exponentially with depth (or its analog, cumulative dry weight), although close-interval dating shows the profiles to be non-monotonic. A major inflection occurs at $30-35 \mathrm{~cm}\left(7-9 \mathrm{~g} / \mathrm{cm}^{2}\right.$ cumulative dry wt.) in the Creel Bay core, while the Main Bay profile is virtually flat between 24 and $34 \mathrm{~cm}$ $\left(6-10 \mathrm{~g} / \mathrm{cm}^{2}\right.$ cumulative dry wt.). The c.r.s. model treats these sections as periods of higher sediment flux as indicated by steep slopes on the age-depth

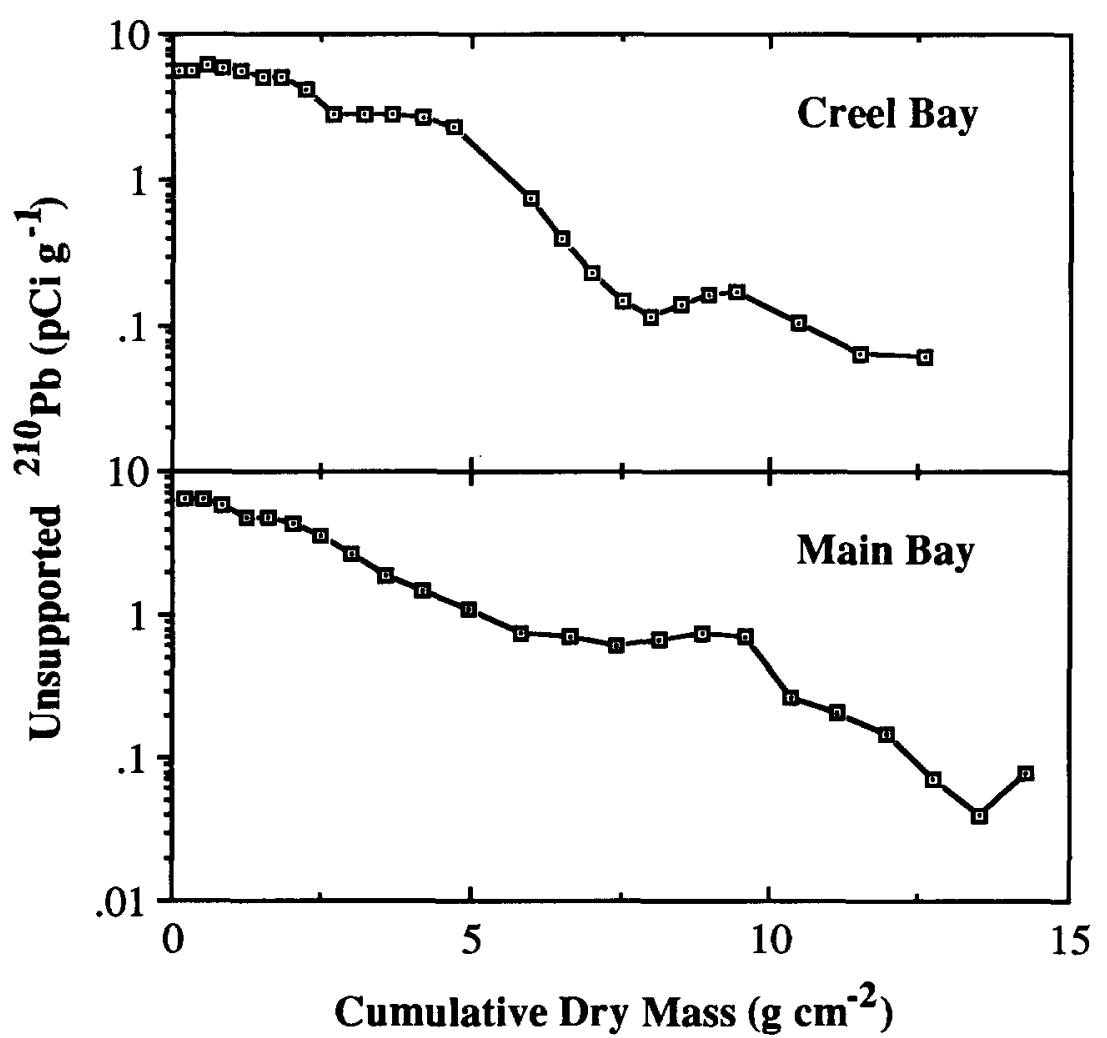

Fig. 5. Unsupported ${ }^{210} \mathrm{~Pb}$ activity profiles from the Creel Bay and Main Bay cores; the error bars for counting precision ( \pm 1 s.d.), if shown, would be generally smaller than the square symbols on the graph. 


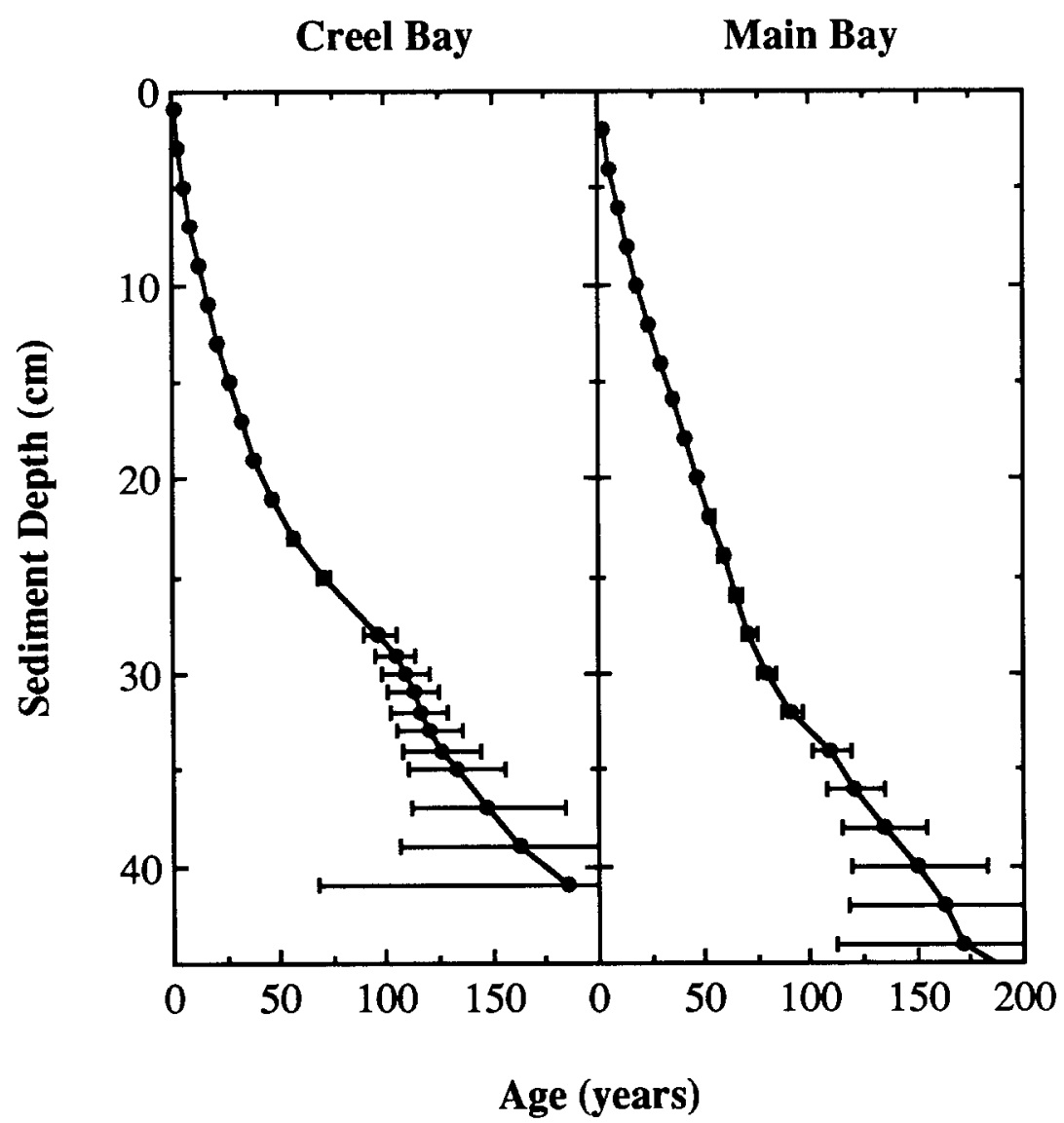

Fig. 6. ${ }^{210} \mathrm{~Pb}$-derived age/depth profiles from the Creel Bay and Main Bay cores; the error bars $( \pm 1$ s.d.) represent first-order propagation of counting precision.

profiles (Fig. 6). Average sediment accumulation is similar for the two basins, but it fluctuates asynchronously between 50 and $150 \mathrm{mg} \mathrm{cm}^{-2} \mathrm{yr}^{-1}$ over the last 200 years (Fig. 7). These changes in accumulation are not correlated with any discernible shift in gross sediment composition (Fig. 8) that should normally accompany changes in material input to a lake (nutrients, clastics, etc.). The accumulation peaks more likely reflect shifts in sediment deposition pattern within the two basins, whereby more material was moved to the core-sites without changing its composition. Despite differences in sedimentary history, the flux of ${ }^{210} \mathrm{~Pb}$ is very similar in Creel Bay and Main Bay $\left(0.653\right.$ and $0.637 \mathrm{pCi} \mathrm{cm}^{-2} \mathrm{yr}^{-1}$, respectively), a condition that supports the use of the c.r.s. dating model.

\section{Presettlement vegetation}

Diagrams of pollen percentages (Fig. 9) from both Creel Bay and Main Bay of Devils Lake reveal that prior to disturbance by Europeans the prairie vegetation was similar to that of the North Dakota Plains described by McAndrews \& Wright (1969). Pollen spectra are characterized by Artemisia $(20-25 \%)$, Wild-Grass Group of Poaceae (10-20\%), and Ambrosia-type (1-5\%). Trees and shrubs such as Acer negundo, Fraxinus pennsylvanica, Ulmus americana, Ostrya virginiana, Populus deltoides var. occidentalis, Corylus cornuta, Alnus spp., and Salix spp. probably occurred in wet, shallow sloughs, which are abundant in the morainal topography surrounding Devils Lake, as well as along the lake shores, where they also 


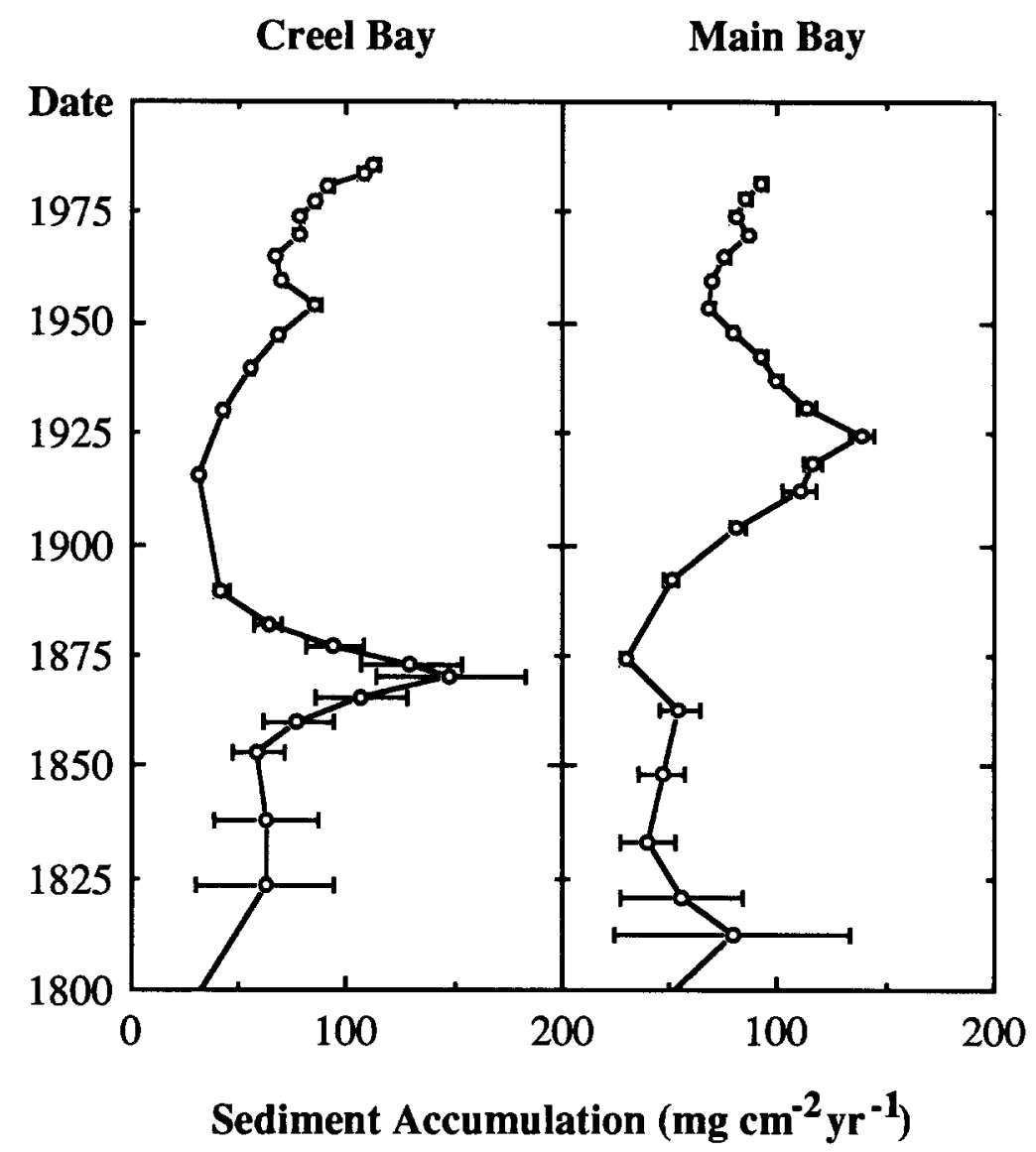

Fig. 7. ${ }^{210} \mathrm{~Pb}$-derived sediment accumulation rates for the Creel Bay and Main Bay cores; the error bars ( \pm 1 s.d.) represent first-order propagation of counting precision.

grow today (Stevens, 1963; Fowells, 1965). Quercus macrocarpa probably occupied drier, more exposed sandy plains and west-facing slopes (Fowells, 1965).

\section{Cultural chronostratigraphic indicators in the pollen record}

As the population of homesteaders increased in the region surrounding Devils Lake, more and more land was converted from native mixedprairie to cultivated fields. Evidence of those changes in land use are preserved in the fossilpollen stratigraphy as the initial appearance of pollen types from imported cultivars, such as wheat (Triticum), rye (Secale), and oats (Avena), and by increases in pollen of native weedy plants such as Ambrosia, Chenopodium-type, and Iva xanthifolia, which proliferate when prairie vegetation is disturbed. Other anthropogenic indicators include deliberately or inadvertently introduced weeds such as Brassica and Salsola iberica (formerly Salsola kali L. var. tenuifolia Tausch and S. pestifer A. Nels.), natives of eastern Europe and western Asia.

The chronostratigraphic value of individual anthropogenic indicators depends upon several factors, including pollen production and transport relative to the size of the collecting basin, historical documentation of events affecting the taxon, sampling interval relative to sedimentation rate, and the number of grains counted per level relative to the vegetation type. These taxa can be separated into three ecological groups: native weeds, cultivars, and introduced weeds. 


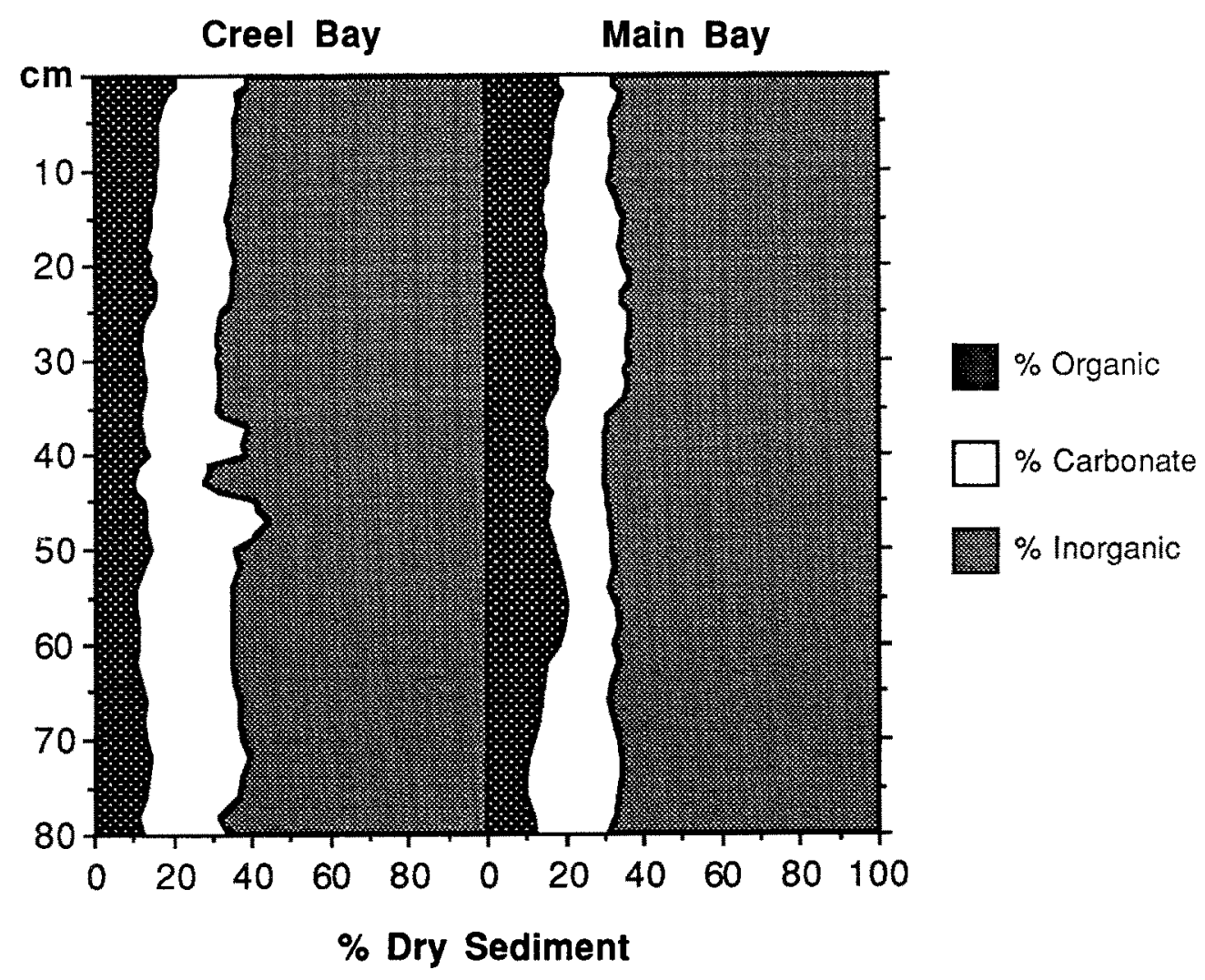

Fig. 8. Sediment composition of Creel and Main Bay sediments as determined by loss-on-ignition.

Native weeds

In the Creel Bay core Ambrosia pollen rises initially from $5 \%$ to $10 \%$ between 35 and $33 \mathrm{~cm}$, and again from $10 \%$ to $15 \%$ between 29 and $27 \mathrm{~cm}$. Chenopodium-type also increases from less than $10 \%$ to over $15 \%$ at $27 \mathrm{~cm}$, after which both taxa remain relatively abundant to the top of the core. There is also a slight increase in Iva xanthifolia at this time.

A marked increase in Ambrosia pollen is considered a reliable indicator of regional and local land clearance and agricultural disturbance across eastern North America (Bradbury \& Waddington, 1973; Brugam, 1978). Discrepancies between radiocarbon dates for the Ambrosia-rise and dates of historically recorded disturbance have often been used to correct radiocarbon dates of long cores (Grimm, 1983; Waddington, 1969).

Chenopodium-type pollen can increase in response to both land disturbance and climatic warming, especially when lake levels are lowered and mud flats become exposed (Wright et al., 1963; Watts \& Winter, 1966). Lake-level records since the late 1860's show that between 1880 and 1890 , just at the beginning of local agricultural expansion, the water depth at Devils Lake decreased by ca. $3 \mathrm{~m}$ (Fig. 2). It is likely that this occurred in other lakes of the region as well. In a gently sloping basin like Devils Lake, a $3 \mathrm{~m}$ drop in water level would result in aerial exposure of a considerable area of lake bottom suitable for colonization by taxa in the family Chenopodiaceae (Fig. 3).

Both Ambrosia and Chenopodiaceae taxa produce large quantities of pollen, which is dispersed over long distances. They compete effectively for water and do well during dry periods. If the collecting basin is large as at Devils Lake, agricultural disturbance and warm or dry climatic events should be detected at some distance.

Iva xanthifolia occurs in rich soils of abandoned 


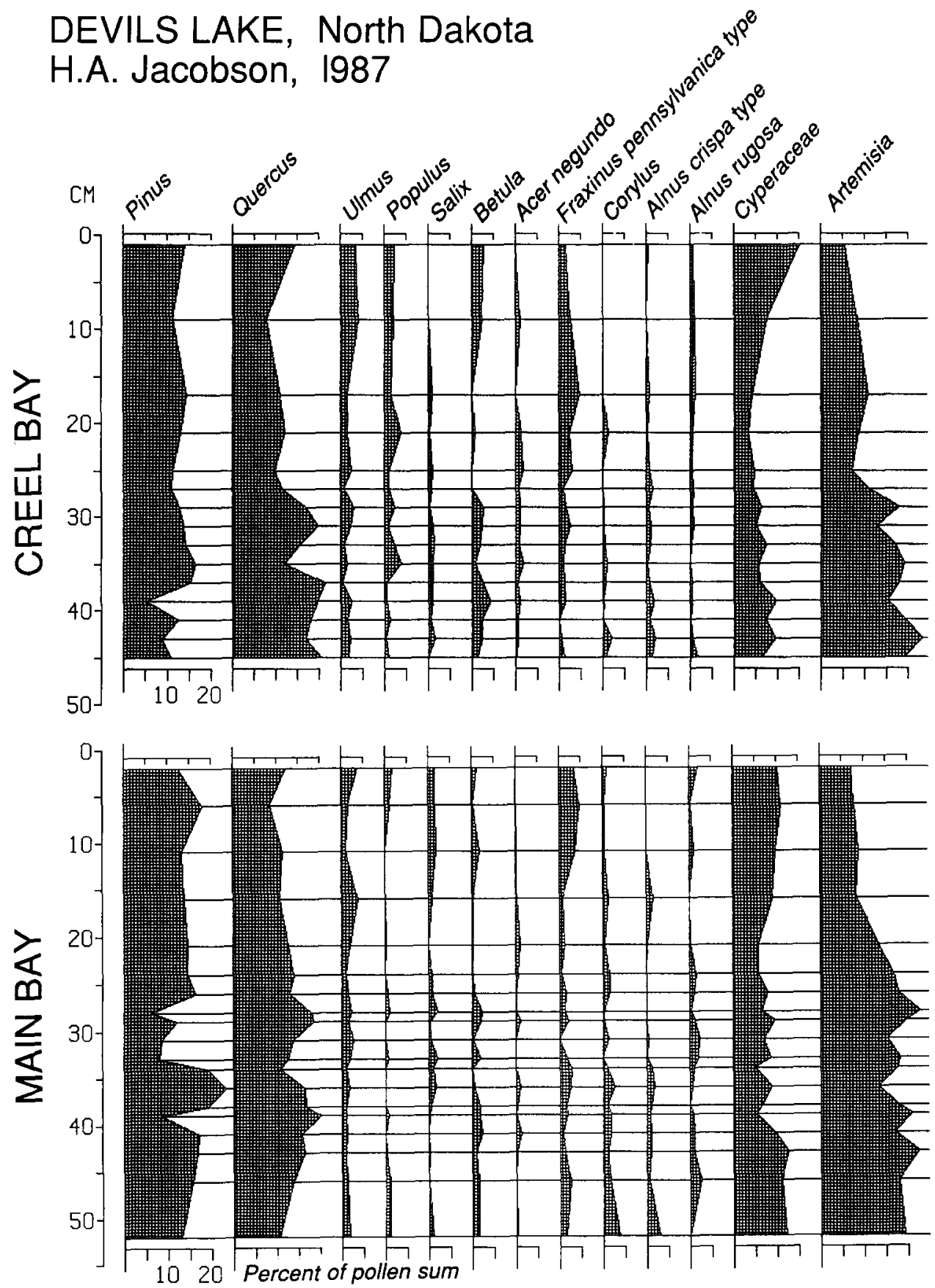

Fig. 9. Diagrams of pollen percentages of selected pollen types from Main Bay and Creel Bay. 

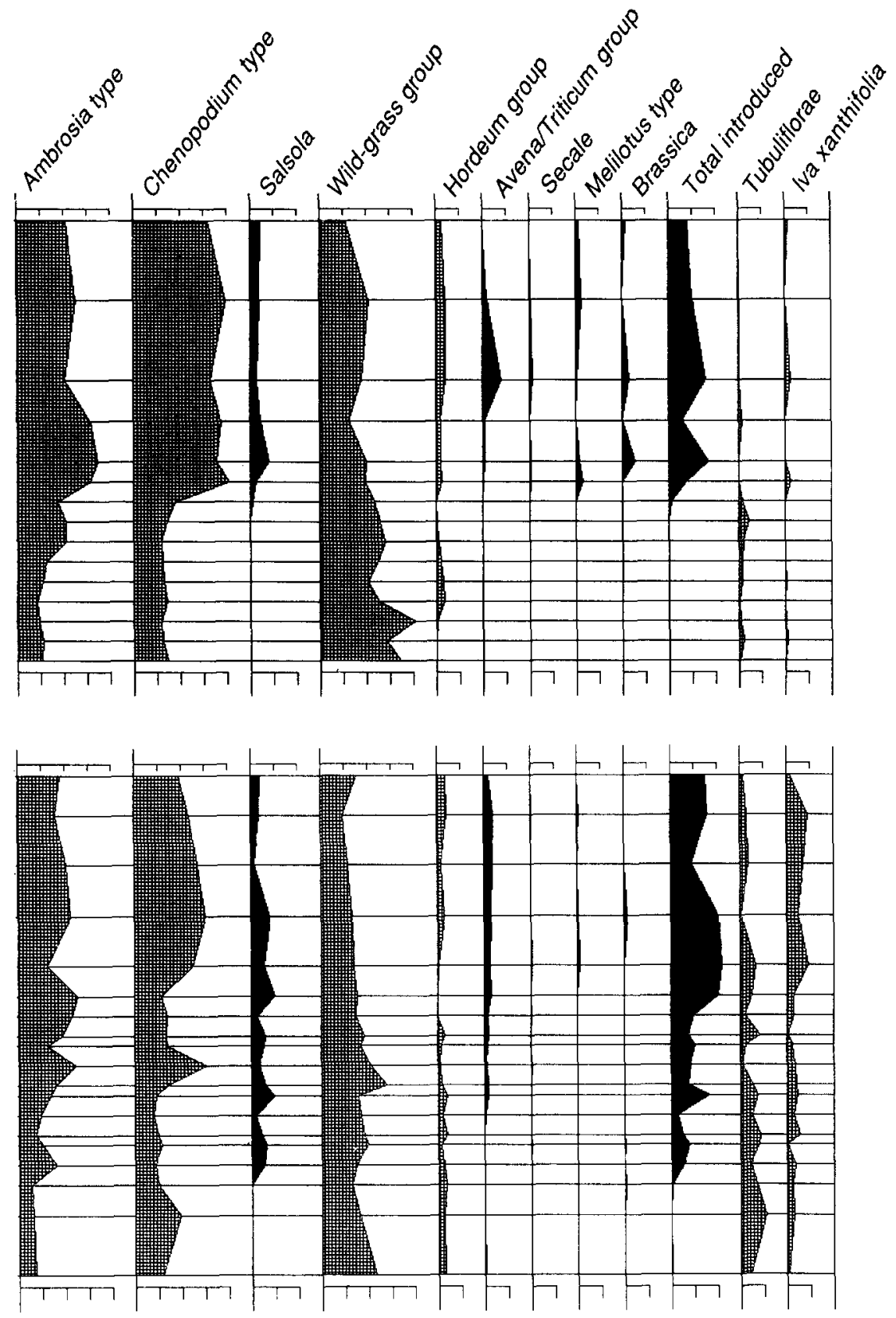
fields and waste places. Its native range in 1847 was from northeast Wisconsin to New Mexico, but by 1894 it had spread from farm to farm into all parts of North Dakota (Pammel, 1894). Its historical appearance at Devils Lake is undocumented.

The fact that Chenopodium-type and Iva xanthifolia pollen increase together with Ambrosia at 29-27 cm in Creel Bay suggests that this depth corresponds to the time of land disturbance that was either more intense or more local than that represented by the first rise in Ambrosia $(35-33 \mathrm{~cm})$, which may correspond to agricultural expansion in the Turtle Mountain region (1870) or to small-scale, local homesteading immediately following the formation of districts in 1873. The second Ambrosia rise probably corresponds to local agricultural expansion related to the opening of new markets by the railroad after 1883.

\section{Cultivars}

Cereals including Avena, Triticum, and Secale have large pollen grains that are not widely dispersed. Avena and Triticum are autogamous (selffertilizing) species; much of their pollen remains in the chaff and is poorly dispersed except during thrashing (Behre, 1981; Vuorela, 1973). Secale is an allogamous (wind-pollinated) species with high pollen productivity. Although the pollen grain is large and rather poorly dispersed (Vuorela, 1973), it does occur in low concentrations in local lake sediments and is considered by Behre (1981) to be among the most reliable indicators of local cultivation.

Thus although the presence of cereal pollen in the sediments is a good indication of local presence of the taxon, its absence does not necessarily indicate local absence of the taxon (Behre, 1981). Historical records at Devils Lake reveal that cereals were grown nearby as early as 1875 . However, pollen concentrations in the sediments probably would not have been high enough to be detected at the pollen levels counted in this study (ca. 300 grains counted per level) until after 1883, when crop production began to increase for export by railroad.
Melilotus albus, $M$. officinalis, Trifolium pratense, and $T$. repens make up the Melilotus-type (clover) group. Clover is a forage crop grown for livestock feed and was probably not abundant until after the railroads began transporting farm animals to the Devils Lake area. Thus the appearance of Melilotus-type pollen in the Creel Bay core at $25 \mathrm{~cm}$ also probably corresponds to sometime after 1883 .

\section{Introduced weeds}

Brassica spp. (wild mustards) are weedy inhabitants of disturbed ground. Although many taxa are known to have been introduced from Eurasia (Rollins, 1981), the locations of introduction and the timing of dispersal are not well documented. Brassica pollen (ca. 3\%) appears in the Creel Bay diagram for the first time at $25 \mathrm{~cm}$; the plants were probably locally present at that time. Unfortunately, the arrival of Brassica can be constrained only to sometime after 1873 .

Unlike Brassica, extensive documentation of the introduction and spread of Salsola iberica allows for a precise estimation of its time of arrival at Devils Lake (1894-1895). Salsola seeds from Russia were introduced to North America near the town of Scotland, Bom Homme Co., South Dakota, in 1873 (Dewey, 1893). The seeds were sown with the imported flaxseed (Linum), of which they were a contaminant.

Salsola iberica is an annual that does well during dry spells. It is capable of taking over cultivated fields to the virtual exclusion of the intended crop, and it can be a serious impediment to farm equipment. Significant reductions in wheat production in Russia and in the Dakotas have been attributed to this weed.

The young Salsola plants are succulent and digestible by livestock, but as they mature they form sharp spines and hard tissues. The mature plants have broad, light, hemispherical forms up to $2 \mathrm{~m}$ in diameter, which are held in place by a small, delicate, root system. The small root breaks under the force of the wind, setting the plant off rolling as a tumbleweed, scattering thousands of seeds in its path. The dried corolla remains attached to the seed and acts like a sail, allowing 
the seed itself to be carried short distances by the wind.

In this manner individual Salsola iberica plants can advance 8 to $15 \mathrm{~km}$ over flat open areas in one season, primarily in the direction of prevailing winds. The spread of seeds is substantially hindered only by streams, hollows, or fences. By
1892 the distribution of the plant was bounded on the west by the Missouri River and on the east by several smaller north-south waterways. Such barriers were overcome, however, as seeds were carried by railroads and in the flaxseed they transported (Dewey, 1893). Salsola's ability to spread is well illustrated in Mack's (1986) discussion of plant invasion in the intermountain West.

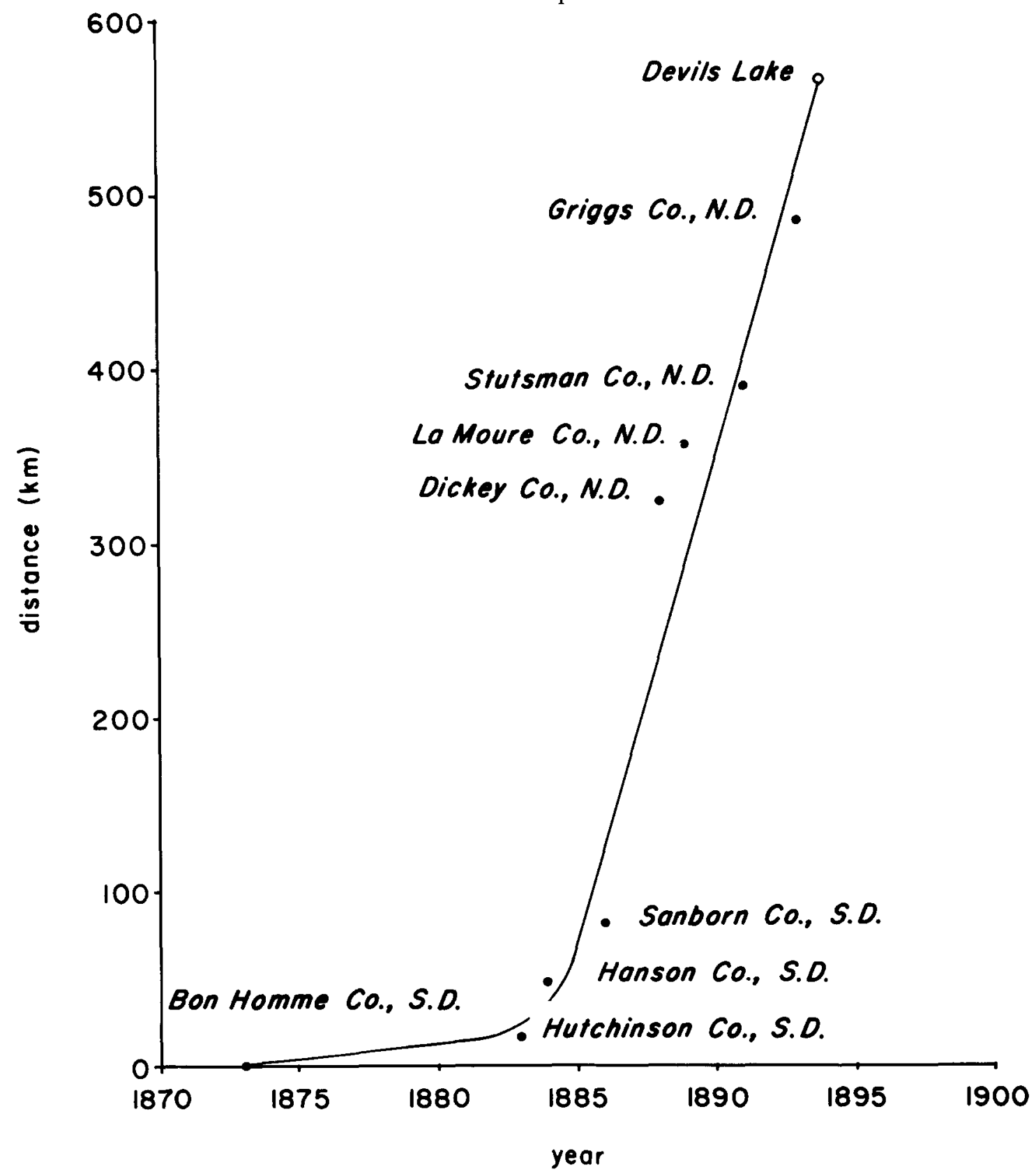

Fig. 10. Migration of Salsola iberica in South Dakota and North Dakota with projected arrival at Devils Lake (after Dewey, 1894). 
The U.S. Department of Agriculture (Dewey, $1893,1894,1895)$ carefully recorded the expansion of Salsola iberica from county to county in South Dakota and into North Dakota as far as Griggs Co., where it arrived in 1893, about $80 \mathrm{~km}$ south of Devils Lake. Figure 10 shows the migration sequence, which includes a lag in the first decade and rapid migration (about $55 \mathrm{~km} / \mathrm{yr}$ ) in the next decade. If that rate was maintained between 1893 and 1894, as models of rates of spread predict (Roughgarden, 1986), Salsola iberica would have been present locally at Devils Lake by 1894 or 1895 .

Like other taxa of the Chenopodiaceae, Salsola produces large quantities of easily dispersed pollen. Salsola pollen could therefore occur in low abundance in sediments of lakes several $\mathrm{km}$ or even tens of $\mathrm{km}$ from the source plants. In this case, however, the rate of migration (ca. $55 \mathrm{~km} / \mathrm{yr}$ ) was such that only two years prior to the arrival of this species at Devils Lake the population would have been too far away $(>100 \mathrm{~km}$ ) for pollen to be detected with the pollen sum used. Assuming a sedimentation rate of $0.125-0.250 \mathrm{~cm} / \mathrm{yr}$, sediment deposited when the plants were locally present would have been less than one $\mathrm{cm}$ above that deposited when the source plants arrived within the range of pollen transport.

\section{Comparison between Main Bay and Creel Bay}

At the settlement horizon represented in both pollen diagrams (Fig. 9), Artemisia pollen decreases, Ambrosia and Chenopodium-type pollen increase, and Avena/Triticum, Secale, Melilotus-type, Brassica, and Salsola pollen appear. Syringa vulgaris (lilac) pollen also appears in Creel Bay samples.

It is doubtful that there are any significant differences in the history of the vegetation surrounding Main Bay and Creel Bay. However, the evidence in the cores of the events listed above differs considerably between the bays. In Creel Bay, all of the changes mentioned are relatively synchronous, occurring between $27-29 \mathrm{~cm}$. In Main
Bay, Avena/Triticum appears first at $53 \mathrm{~cm}$ but not again until $37 \mathrm{~cm}$; Brassica first appears at $44 \mathrm{~cm}$, Salsola at $41 \mathrm{~cm}$, Secale at $40 \mathrm{~cm}$, and Melitous-type at $17 \mathrm{~cm}$.

The timing of the arrival of Salsola iberica provides the best check on the reliability of the Main Bay stratigraphy. Salsola appears for the first time at $41 \mathrm{~cm}$ in the Main Bay core; it may occur as low as $42 \mathrm{~cm}$, which was not analyzed for pollen. Sediments at $41 \mathrm{~cm}$ corresponds to ca. 1825 by ${ }^{210} \mathrm{~Pb}$ dating, 60 years earlier than the arrival of the species. The pollen and ${ }^{210} \mathrm{~Pb}$ chronostratigraphies in Main Bay cannot be reconciled. Nor can it be assumed that the pollen record is necessarily accurate and the ${ }^{210} \mathrm{~Pb}$ measurements faulty.

Historical records indicate that most of the palynological changes related to settlement should occur during the decade following 1883 , when the railroad reached Devils Lake, including 1894, when Salsola arrived. (Before that time farming occurred at a rather small scale; little in the way of cultivars, livestock, weeds, or ornamentals such as Syringa had been imported.) The period of agricultural expansion would be represented within approximately $2-3 \mathrm{~cm}$ in the stratigraphic record (Fig. 4), rather than $10-20 \mathrm{~cm}$ as is suggested in the Main Bay diagram (Fig. 9).

In the Creel Bay core the correspondence between pollen and ${ }^{210} \mathrm{~Pb}$ chronologies could not be better. The ${ }^{210} \mathrm{~Pb}$ date at $28 \mathrm{~cm}$ is $1889 \pm 7$ years ( \pm 1 s.d.); the settlement horizon at $27-29 \mathrm{~cm}$ in the pollen record dates to $1889 \pm 5$ years. Such good results are somewhat surprising for Devils Lake in the light of the large hydrologic fluctuations of the last 100 years, which easily could have altered sedimentary conditions in the basin.

By contrast, dating of the Main Bay could hardly be more ambiguous. Lead-210 gives an explicit date of $1892 \pm 5$ years $( \pm 1$ s.d. $)$ at $32 \mathrm{~cm}$, but abundant agricultural pollen occurs well below this level. While there is nothing in the ${ }^{210} \mathrm{~Pb}$ stratigraphy to indicate violation of the c.r.s. dating model, the fact that the pollen stratigraphy is so highly smeared suggests that sediment redeposition may have occurred. A large, 
shallow, flat-bottomed basin such as the Main Bay of Devils Lake presents a nearly ideal site for advective transport of fine-grained sediments. Sediment and ${ }^{210} \mathrm{~Pb}$ accumulation might have been episodic, shifting about the basin as a complex result of lake level and wind-induced turbulence.

If ${ }^{210} \mathrm{~Pb}$ accumulation varied with the flux of redeposited sediment, the assumption of a constant ${ }^{210} \mathrm{~Pb}$ supply to the coring site would be invalid. However, the nearly identical unsupported ${ }^{210} \mathrm{~Pb}$ burdens in the Creel and Main Bay cores (20.46 and $20.97 \mathrm{pCi} \mathrm{cm}^{-2}$, respectively) argue against this hypothesis. A highly variable ${ }^{210} \mathrm{~Pb}$ flux is unlikely to produce a similar inventory of unsupported ${ }^{210} \mathrm{~Pb}$ at two such dissimilar core sites. Instead the dating discrepancy might have been caused by severe mixing of the upper sediment column.

The presence of anthropogenic pollen well below the lead-dated settlement horizon in the Main Bay core could be explained by the ${ }^{210} \mathrm{~Pb}$ date being too old. However, sediment mixing has exactly the opposite affect on ${ }^{210} \mathrm{~Pb}$ dating; mixing enriches older sediments with ${ }^{210} \mathrm{~Pb}$, making them appear younger, not older. Alternatively the source of error might reside in the pollen stratigraphy itself. The direction of error in pollen dating would be the same as that for ${ }^{210} \mathrm{~Pb}$; new pollen taxa would be displaced down core, the settlement horizon would be incorrectly placed at greater depth, and ages extrapolated from this marker would be too young.

Because pollen markers are much more strongly affected by mixing than ${ }^{210} \mathrm{~Pb}$ dates, it is possible for mixing to produce the dating discrepancy found in the Main Bay core, though causing both dating methods to err in the same direction. According to the c.r.s. model, the true ${ }^{210} \mathrm{~Pb}$ age $t$ of sediments at core depth $i$ in the presence of rapid steady-state mixing is given by

$$
t_{i}=1 / k \ln A_{o} /\left(A_{i}+W C_{i}\right)+W / R_{i}
$$

where $A_{o}$ is the unsupported ${ }^{210} \mathrm{~Pb}$ burden for the entire core, $A_{i}$ is the integrated unsupported activity below depth $i, k$ is the ${ }^{210} \mathrm{~Pb}$ decay constant $\left(0.03114 \mathrm{yr}^{-1}\right), W$ is the cumulative dry mass of the mixed layer, $C_{i}$ is the unsupported ${ }^{210} \mathrm{~Pb}$ concentration at depth $i$, and $R_{i}$ is the sediment accumulation rate (Oldfield \& Appleby, 1984). If we assume that the zone of mixing in the Main Bay core is represented by the discrepancy between the cultural-pollen horizon at $40 \mathrm{~cm}$ and the ${ }^{210} \mathrm{~Pb}$ date of 1889 , iteration of the above model yields a value of $\mathrm{ca} .10 \mathrm{~cm}\left(3.8 \mathrm{~g} \mathrm{~cm}^{-2}\right.$ cumulative dry mass) for the thickness of the mixed layer. Note that this value is greater than the $8 \mathrm{~cm}$ difference between pollen and ${ }^{210} \mathrm{~Pb}$ dates assuming no mixing, and that $3.8 \mathrm{~g} \mathrm{~cm}^{-2}$ represents a modern mixed depth of $18 \mathrm{~cm}$ (density corrected).

This amount of sediment is clearly unrealistic, although less severe mixing could still contribute to some of the discrepancy observed between pollen and lead-based chronologies. The downward displacement of sufficient exotic pollen to ensure the detection of a few grains in precultural sediments would require far less vigorous mixing than that envisioned in the above example. A mixed depth of $10-12 \mathrm{~cm}$ and only partial homogenization might suffice. The strongest evidence for altered pollen stratigraphy in the Main Bay core is the gradual and asynchronous appearance of the introduced pollen taxa.

The marked contrast in sediment chronology between two contiguous basins of Devils lake clearly demonstrates the importance of site selection in high-resolution stratigraphic studies on lakes of the Great Plains. Generally shallow depths, strong winds, and little shoreline protection create a high-energy sedimentary environment in most basins. Many of these lakes also exhibit marked fluctuations in depth and surface area in response to hydrologic change. Combined with wind-induced turbulence, changing lake levels can alter sediment deposition patterns in unpredictable ways, obscuring stratigraphy and any subsequent effort to date it.

Dating success in Creel Bay and failure in Main Bay is probably linked to basin morphometry. While the two basins are nearly equal in depth, Creel Bay is narrow (ca. $1 \mathrm{~km}$ ) in the direction of prevailing winds, while Main Bay is roughly circu- 
lar and more than $8 \mathrm{~km}$ across. Wind stress mixes the water column of Main Bay throughout the year except during periods of ice cover, and with its pan-like morphometry it is not hard to imagine the active resuspension and transport of sediments, particularly at low lake stage.

In contrast, the sharp resolution of the Creel Bay pollen record and its precise correspondence to independent dating by ${ }^{210} \mathrm{~Pb}$ argues against significant disturbance of sediment stratigraphy by mixing or episodic events. Clearly defined features in diatom and ostracode stratigraphy in the upper sediments (unpublished data) provide further evidence against substantial mixing in this core. A temporal resolution of 5 years in Creel Bay is probably nearly optimal for pollen dating and is only possible where stratigraphy is well preserved and vegetational change is both rapid and well documented. Because of unstable sedimentary conditions and a high flux of clastic sediments, lakes of the Great Plains are not ideal sites for ${ }^{210} \mathrm{~Pb}$ dating. It is precisely under such conditions that independent dating techniques are required to resolve reliably the chronology of recent lake sediments.

\section{Acknowledgements}

We are indebted to R. N. Mack, E. C. Grimm, and Mrs. H. R. Rutten, President of the Devils Lake Historical Society, for providing useful information. H. E. Wright, Jr., M. W. Binford, and an anonymous reviewer offered helpful criticisms and suggestions, and H. E. Wright, Jr. assisted with computer graphics. This work was supported by a grant from NSF (BSR-8415866). This paper is contribution no. 387 of the Limnological Research Center.

\section{References}

Andersen, S. T., 1979. Identification of wild grass and cereal pollen. Danm. Geol. Unders. Arbog 1978: 69-92.

Appleby, P. G. \& F. Oldfield, 1978. The calculation of lead-210 dates assuming a constant rate of supply of the unsupported ${ }^{210} \mathrm{~Pb}$ to the sediment. Catena 5: 1-8.
Appleby, P. G. \& F. Oldfield, 1983. The assessment of ${ }^{210} \mathrm{~Pb}$ data from sites with varying sediment accumulation rates. Hydrobiologia 103: 29-35.

Appleby, P. G. \& F. Oldfield, 1988. The use of nuclear techniques in sediment transport and sedimentation problems. In Radioisotope studies of recent lake and reservoir sedimentation (in press).

Aronow, S., 1957. On the postglacial history of the Devils Lake region, North Dakota. Journal of Geology 65: 410-427.

Beadle, J. C., 1973. Russian-thistle (Salsola) species in western United States. Journal of Range Management 26: 225-226.

Behre, K.-E., 1981. The interpretation of anthropogenic indicators in pollen diagrams. Pollen et Spores 23: 225-245.

Benninghoff, W. S., 1962. Calculation of pollen and spore density in sediments by addition of exotic pollen in known quantities. Pollen et Spores 4: 332-333.

Beug, H. J., 1961. Leitfaden der Pollenbestimmung. 1. G. Fischer. Stuttgart. 63 pp.

Binford, M. W., 1988. ${ }^{210} \mathrm{~Pb}$ dates and their associated uncertainties for PIRLA cores (in press).

Bradbury, J. P. \& J. C. B. Waddington, 1973. The impact of European settlement on Shagawa Lake, northeastern Minnesota, U.S.A. In: H. J. B. Birks \& R. G. West (eds.), Quaternary Plant Ecology, 14th Symp. British Ecological Society, Blackwell Scientific Pub., Oxford.

Brooks, R. D., 1986. Salsola. In Great Plains Flora Association, Flora of the Great Plains, p. 176-177. University Press of Kansas, Lawrence.

Brugam, R. B., 1978. Human disturbance and the historical development of Linsley Pond. Ecology 59: 19-36.

Callendar, E., 1968. The Postglacial Sedimentology of Devils Lake, North Dakota. PhD Thesis. University of North Dakota.

Cushing, E. J., 1967. Evidence for differential pollen preservation in late Quaternary sediments in Minnesota. Review of Paleobotany and Palynology 4: 87-101.

Davis, R. B., C. T. Hess, S. A. Norton, D. W. Hanson, K. D. Hoagland \& D. S. Anderson, 1984. ${ }^{137} \mathrm{Cs}$ and ${ }^{210} \mathrm{~Pb}$ dating of sediments from soft-water lakes in New England (U.S.A.) and Scandinavia, a failure of ${ }^{137}$ Cs dating. Chemical Geology 44: 151-185.

Dewey, L. H., 1893. The Russian Thistle. U.S.D.A. Farmers Bulletin No. 10. 10 pp.

Dewey, L. H., 1894. The Russian Thistle: its history as a weed in the United States, with an account of the means available for its eradication. U.S.D.A. Division of Botany Bulletin, No. 15, 26 pp.

Dewey, L. H., 1895. Distribution of the Russian Thistle in North America. Botanical Gazette 20: 501.

Drache, H. M., 1970. The Challenge of the Prairie. North Dakota Institute for Regional Studies, Fargo, N.D.

Eakins, J. D. \& R. T. Morrison, 1978. A new procedure for the determination of lead-210 in lake and marine sediments. International Journal of Applied Radiation and Isotopes 29: 531-536. 
Faegri, K. \& J. Iversen, 1975. Textbook of Pollen Analysis. Hafner Publishing Co., New York, 237 pp.

Fowells, H. A., 1965. Silvics of Forest Trees of the United States. U.S.D.A. Division of Timber Management Res., Forest Service, Agriculture Handbook No. 271, Washington, D. C.

Great Plains Flora Association, 1986. Flora of the Great Plains. University Press of Kansas, Lawrence. 1392 pp.

Grimm, E. C., 1983. Chronology and dynamics of vegetation change in the prairie-woodland region of southern Minnesota, U.S.A. New Phytologist 93: 311-350.

Jacobson, G. L., Jr. \& R. H. W. Bradshaw, 1981. The selection of sites for paleovegetational studies. Quaternary Research 16: 80-96.

Lounsberry, C. A., 1919. Early History of North Dakota. Liberty Press, New York, 645 pp.

Mack, R. N., 1986. Alien plant invasion into the intermountain West: a case history, pp. 191-213. In H. A. Mooney \& J. A. Drake (eds.), Ecology of Biological Invasions of North America and Hawaii. Springer Verlag, New York

McAndrews, J. H., A. A. Berti \& G. Norris, 1973. Key to the Quaternary Pollen and Spores of the Great Lakes Region, Life Sci. Misc. Publ., Royal Ontario Museum. 61 pp.

McAndrews, J. H. \& H. E. Wright, Jr., 1969. Modern pollen rain across the Wyoming Basins and the Northern Great Plains (U.S.A). Review of Paleobotany and Palynology 9: $17-43$.

Oldfield, F. \& P. G. Appleby, 1984. Empirical testing of ${ }^{210} \mathrm{~Pb}$ dating models. In E. Y. Haworth \& J. W. G. Lund (eds.) Lake Sediments and Environmental History. University of Minnesota Press, Minneapolis.

Pammel, L. H., 1894. Distribution of some weeds in the United States, especially Iva xanthifolia, Lactuca scariola, Solanum corolineum, and Solanum reostratum. Iowa Academy of Science Proceedings 2: 103-127.

Reitz, L. P., 1954. Wheat breeding and our food supply. Econ. Bot. 8: 251-268.
Robinson, E. B., 1966. History of North Dakota. University of Nebraska Press, Lincoln. 599 pp.

Rollins, R. C., 1981. Weeds of the Cruciferae (Brassicaceae) in North America. Journal of the Arnold Arboretum 62: $517-540$.

Roughgarden, J., 1986. Predicting invasions and rates of spread, pp. 179-188, in H. A. Mooney \& J. A. Drake (eds.), Ecology of Biological Invasions of North America and Hawaii. Springer Verlag, New York.

Severson, E., 1924. History of Crary. Collections State Historical Society of North Dakota 7: 283-295.

Simpson, H. E., 1912. The physiography of the Devils-Stump Lake region, North Dakota. North Dakota Geologic Survey, 6th Bienn. Report., pp. 101-157.

Simpson, H. E., 1929. Geology and ground water resources of North Dakota. U.S.G.S. Water Supply Paper 598.

Stevens, O. A., 1963. Handbook of North Dakota Plants. North Dakota Institute for Regional Studies, Fargo. $324 \mathrm{pp}$.

Stoermer, E. F., S. M. Taylor \& E. Callendar, 1971. Paleoecological interpretation of the Holocene diatom succession in Devils Lake, North Dakota. Trans. am. Micros. Soc. 90: 195-206.

Swenson, H. A. \& B. R. Colby, 1955. Chemical quality of surface waters in Devils Lake basin, North Dakota. U.S. Geological Survey, Water Supply Paper, 1295.

Vuorela, I., 1973. Relative pollen rain around cultivated fields. Acta Botanica Fennica 102: 1-27.

Waddington, J. C. B., 1969. A stratigraphic record of the pollen influx to a lake in the Big Woods of Minnesota. Geol. Society of America Special Paper 123: 263-282.

Watts, W. A. \& T. C. Winter, 1966. Plant macrofossils from Kirchner Marsh - a paleoecologic study. Geological Society of America Bulletin 77: 1339-1360.

Wright, H. E., Jr., T. C. Winter \& H. L. Patten, 1963. Two pollen diagrams from southeastern Minnesota; Problems in the late- and postglacial vegetational history. Geological Society of America Bulletin 74: 1371-1396. 